European journal of American studies

\title{
Un/Detectability in Times of "Equality": HIV, Queer Health, and Homonormativity
}

Jan Huebenthal

\section{(2) OpenEdition \\ Journals}

Electronic version

URL: https://journals.openedition.org/ejas/11729

DOI: $10.4000 /$ ejas. 11729

ISSN: 1991-9336

Publisher

European Association for American Studies

\section{Electronic reference}

Jan Huebenthal, "Un/Detectability in Times of "Equality": HIV, Queer Health, and Homonormativity", European journal of American studies [Online], 11-3 | 2017, document 5, Online since 13 March 2017, connection on 08 July 2021. URL: http://journals.openedition.org/ejas/11729 ; DOI: https://doi.org/ 10.4000/ejas. 11729

This text was automatically generated on 8 July 2021.

Creative Commons License 


\title{
Un/Detectability in Times of "Equality": HIV, Queer Health, and Homonormativity
}

\author{
Jan Huebenthal
}

\section{Introduction ${ }^{1}$}

1 Near the end of the first season of ABC's popular show How To Get Away with Murder, the promiscuous heartthrob Connor rekindles a relationship with the nerdy Oliver, and they decide to get tested for STDs. In a dramatic turn of events, it is Oliver's HIV antibody test that comes back positive-and so unfolds a storyline, picked up in the premiere episode of the second season, that tackles HIV, safer sex practices, and postdiagnosis romantic life. With great candor, Connor and Oliver have open discussions about what Oliver's serostatus will mean for them. Connor embarks on a PrEP (preexposure prophylaxis) regimen and the two anxiously wait to have sex until the drug can become effective in preventing HIV transmission. Throughout, Oliver remains the disciplined voice of reason even as the hypersexual Connor attempts to pressure him into having sex before the end of the recommended waiting period. Swapping AIDS stigma for level-headed and frank discussion, Murder became one of the first major network TV shows to feature PrEP.

Ine devoting screen time to one of the many medical technologies that has revolutionized HIV prevention and treatment, Murder avoided the narrative trope of HIV diagnosis as a sure "death sentence" and instead moved the story to the realm of treatment, management, and future life.In the process, it positions monogam-ish gay couplehood and personal accountability as representational pillars of a new HIVpositive "homo normal." As medical advances have made HIV prevention simpler and survival possible, popular narratives about prevention and treatment have gone a long way to de-stigmatize HIV infection. However, such narratives often also gloss over the multiple layers of racial and political privilege from within which they emerge. In 
particular, fantasies about "undetectable" viral loads-referring to HIV-positive bodies that, through continuous medical treatment, return to statistically insignificant and non-contagious viral loads-fail to account for structural oppressions. "Undetectable" is more than a descriptive feature of successful HIV treatment: It connotes privilege and fitness for citizenship. Indeed, "undetectable" promises a post-AIDS world inhabited by gay men who, having suffered though the horrors of AIDS, have returned to their healthy, authentic selves-and are now "armed with just the right amount of [behavioral] modification" needed to manage HIV (Race 170).

Instruth, race, class, and wealth disparity-in various and mutually constitutive configurations-continue to inform which bodies gain access to healthiness and which ones are at risk for illness. For example, African American men who have sex with men are eight times more likely than whites to be diagnosed with HIV, and one in two gay black men will likely be diagnosed with HIV in his lifetime-but African Americans face low rates of access to and retention in HIV care (Editorial, The New York Times, 29 Feb 2016). Reflecting the persistence of the "queer color line," this statistic illustrates the ways in which race, class, and sexuality circumscribe the attainment of queer health and healthiness. In that way, the healthy, "undetectable" HIV-positive queer subject remains bound to tight grids of exclusion.

Situated at intersections of queer studies, disability studies, and cultural studies, this essay echoes David Román's call to “continue to prioritize AIDS in discussions of contemporary gay culture and politics" (1). In so doing, it accounts in broad strokes for dramatic historical shifts in the relationship of LGBT Americans to the U.S. nation state-a shift that has made some "queer outsiders" into "queer insiders." The attainment, maintenance, and management of queer health and healthiness-moving away from the deadliness of AIDS and towards the manageable chronicity of HIV-have been critical for these historical changes. However, as Jonathan Metzl has pointed out, the very notion of health is "replete with value judgments, hierarchies, and blind assumptions that speak as much about power and privilege as they do about well-being" (1-2). Health, in other words, is no singular, universal value to which everyone has equal access but a prescriptive and ideological set of discourses that throws into relief rigid social hierarchies. In attending to the ethical residues of recent LGBT rights "victories"-as evidenced by Supreme Court rulings decriminalizing "sodomy" in 2003 and legalizing same-sex marriage nationwide in 2015-I argue that access to the private spheres of marriage, child-rearing, and inheritance has come at the expense of the health of vulnerable populations and breathed new life into historical specters of homophobia and AIDS stigma. Moving into a "post-AIDS" age of chronicity, treatment, and future, HIV/AIDS has come to function as a fault line of normative queer subjectivity. Systemic critique has, by and large, given way to imperatives of personal responsibility that gloss over the vast structural exclusions that restrict access to HIV care and treatment.

The goal of this essay is to track the discursive grids of power and privilege that run through the homonormative HIV-positive queer subject. Homonormativity, a term coined by Lisa Duggan, refers to queer citizens' uncritical acquiescence in statesanctioned political formations that foreground domesticity and consumption while nurturing depoliticized and hegemonic hierarchies of race, class, gender, and ability ("The New Homonormativity" 179). Through a disability studies lens, this essay theorizes how homonormative health care arrangements disable and discard certain 
bodies while, at the very same time, they work to en-able and restore normalcy to others. Some of the questions this essay engages are: Who has actually gained access to the ableist fantasies of inclusivity that herald a healthy, "post-AIDS" queer life but fail to protect those who fall outside of the parameters of "normative" queerness? What are the ideological mechanisms through which queer healthiness is made universally desirable but not universally attainable? And what is the work that race does in delineating the boundaries of homonormative HIV-positive subjectivity and restricting access to HIV care and prevention?

Methodologically, this essay shifts between historical analysis and theoretical intervention. This approach reflects an understanding that queer studies can productively blend histories and theories in ways that may blur their separate contours but sharpen their collaborative powers. The first two sections ("From Activism to Individualism" and "Desiring the State: The Ambivalent Gift of Recognition") historicize political-discursive shifts over the last three decades that have allowed for conditional legal inclusion of queer U.S. citizens. In so doing, they theorize how HIV/ AIDS has both facilitated and complicated those shifts. Juxtaposing two sets of narrative images-an angry ACT UP demonstration at the 1987 Third International Conference on AIDS and a 2014 HIV prevention campaign by the Centers for Disease Control and Prevention (CDC)-these sections also seek to contextualize monumental political changes in public HIV/AIDS work. As the AIDS epidemic catalyzed much of U.S. LGBT rights politics, the emphasis those politics placed on civic inclusion, rights to privacy, and citizenship rights laid the foundation for new fault lines of exclusion.

Tracing those fault lines along the relationship of homonormativity to racial privilege, the following section, "Homonormativity: Whiteness, Health, and Privilege," examines how triumphant narratives of managed HIV infection emanate from and within goals of state inclusion and assimilation, often to the detriment and exclusion of queers of color. In broad strokes, this section argues that an emphasis on personal, rather than systemic, responsibility has tied access to HIV care and survival to grids of racial, economic, and ultimately individual privilege. The penultimate section, "AIDS Stigma and Gay Shame: Leaving the "Community of Pariahs,"' argues that continuous deployments of AIDS stigma secure normative LGBT subjectivity by mobilizing historical arsenals of shame, from which the newly rights-bearing U.S. queer citizen has supposedly gained immunity. Lastly, "HIV and Disability: Fantasies of Inclusivity" examines how ideologies of ability converge with imperatives of disciplined sexuality to engender and sustain post-AIDS queer fantasies. Further, it explores how a queer disability studies approach can productively restore systemic critique to public conversations about HIV/AIDS-a theme reiterated in the conclusion.

\section{From Activism to Individualism}

On June 1, 1987, as the Third International Conference on AIDS opened in Washington, D.C., activists affiliated with ACT UP (AIDS Coalition to Unleash Power) convened in the capital to protest the inaction of Ronald Reagan's administration in the face of the HIV/AIDS epidemic in the United States. At the conference opening ceremonies the night before, President Reagan had delivered his first public speech on AIDS-ending his silence of more than six years. ${ }^{4}$ Rather than announcing an increase in funding for medical research or education programs, however, Reagan called for 
more widespread and routine antibody testing. His proposal drew loud boos from the scientists, doctors, public health officials, and fundraisers in the audience. The following evening, Vice President George Bush, echoed Reagan's demand for an increase in testing, drawing similar boos. Unaware that his microphone was still on, Bush whispered to an aide, "What is it, some kind of gay group out there?" (Crimp with Rolston, 32-33).

Outside, ACT UP protesters clashed violently with the police and 64 activists were arrested. In what would become an iconic symbol of police action against ACT UP, the arresting officers donned yellow rubber gloves, reflecting a fear of "catching AIDS." In response, the activist group chanted, "Your gloves don't match your shoes! You'll see it on the news!" (Stein 112) ACT UP protesters responded to a broader sense of discrimination at the hand of the U.S. nation state, exemplified by actions of thenAttorney General Edwin Meese. In 1986, Meese had decreed that a person with AIDS (PWA), or even a person suspected of having AIDS, could be fired as long as the employer could credibly assert not having known that the employee had AIDS and claim ignorance of the fact that AIDS could not be transmitted through casual contact. (A fact of which, evidently, the Washington police at the Third International Conference on AIDS was likewise ignorant.) In the absence of a national education campaign, ACT UP argued, employer's ignorance, truthful or feigned, could be all but guaranteed-and PWAs remained vulnerable to discrimination and loss of employment (Crimp with Rolston 32). ${ }^{5}$

The American nation state, personified by presidents, attorneys general, public health officials, and conservative "everyday" citizens, placed AIDS in direct relation to (homo)sexual deviance. Purportedly out of concern for the integrity of the "general public"-a rhetorical figure which Leo Bersani has termed "at once an ideological construct and a moral prescription" (203)-homophobic voices constructed a potent moral fantasy about the American nation. The fact that President Reagan and then-Vice President Bush emphasized antibody testing over medical research reflected this fantasy: The aim was not to treat or cure, but to identify, isolate, and ultimately eradicate the moral dangers of AIDS. As a result, those who had historically already been marginal in American society-gay men and lesbians, sex workers, and intravenous drug users-were further marginalized by the advent of AIDS because they symbolized a threat of physical as well as moral contagion.

In the late 1980s and early 1990s, ACT UP staged a number of high-profile protest actions at locations like the White House, New York City's city hall, and various offices of the United States Postal Service, demanding education, challenging the medical establishment, and drawing attention to social issues exacerbated by HIV/ AIDS: poverty, racism, and homophobia. At every turn, ACT UP chanted their (in)famous slogan "SILENCE = DEATH" because they understood "language, discourse, and public manifestations [as] necessary weapons of defense in a contemporary strategy of gay survival" (Edelman 302). In 1988, for example, activists shut down the New York office of the Food and Drug Administration for a day, protesting the agency's slow pace in testing, approving, and releasing life-saving medications (McRuer, "Compulsory Able-Bodiedness" 306). Nothing less than bare survival was at stake.

Over the course of the 1990s and 2000s, as the energetic activism of ACT UP and others gradually subsided, HIV/AIDS discourses evolved toward greater emphasis on individual responsibility for prevention and care. As Kane Race notes dryly, the AIDS 
"[crisis] was individuated" (185). As mainstream LGBT rights-based political movements paved the way to the domestic sphere-where queer people may now practice "sodomy" with impunity, get married, and raise children-HIV care became closely tied to knowledge of the self, and ultimately care of the self. The activist histories of AIDS-with the memories of suffering, grief, anger and trauma they evoked -gave way to modes of civic belonging that began locating HIV infection not as a structural or public health concern, but as a personal problem. In the meantime, HIV/ AIDS transitioned from the "gay plague" to a manageable chronic illness-but only if the HIV-positive individual enjoyed access to financial and political capital as well as to quality health care. Narratives that reflect this shift, as seen in How To Get Away With Murder, have worked to de-stigmatize HIV while incentivizing individual modalities of surveillance and care.

Toz give an example, in May, 2014, the Centers for Disease Control and Prevention (CDC) launched a PSA campaign titled "Start Talking. Stop HIV." The video series features about three dozen amateur gay male actors who star as couples in a variety of intimate situations-in a steamy bathroom, between the bed sheets, or taking a stroll along the river. Most of the videos feature gay men who, we are later told, contracted the HI virus through sexual transmission. A disembodied narrator emphatically repeats the phrase "start talking" and stresses the imperative of disclosure-"whether you're looking for Mr. Right or Mr. Right Now, never stop talking." The disclosures themselves are enacted in a range of settings, as a trembling confessional over coffee, as intimate pillow talk, or during a walk in the park (CDC, "Start Talking").

A 14making of" video, posted to the CDC's YouTube page, features personal testimonies from the men involved in the campaign. With great insistence and enthusiasm, the amateur actorstestify to the importance of discussing their serostatus and keeping up on their medication regimens. Through urging gay men to "keep talking" about their health-a veritable Foucauldian "incitement to discourse" (History of Sexuality 56)-the PSAs locate particular modes of self-care in the pursuit of an "undetectable viral load" and/or a "high CD4 count" (referring to maintaining a high number of cells that make up a healthy immune system.) While mentioning condom use and "new" forms of medication, the campaign implies-through soft focus images of handsome, ethnically diverse gay couples, accentuated by emotive music-that good and honest communication between sex partners, and the responsible choices resulting from this communication, will keep HIV at bay. In these PSAs, produced by the leading national public health institute in the U.S., HIV prevention and care figure less as a public health issue than one of individual responsibility. Reminiscent of a TV commercial, the videos seem to "sell" a particular trope of gayness, one predicated on personal responsibility, material privilege, and taken-for-granted healthiness. The medical and bodily realities of HIV remain absent from these images, and prevention figures as a desirable lifestyle choice premised on the absence of disabling illness. Moreover, the campaign universalizes a trope of affluent gayness in which access to health care is a given. Like Connor and Oliver on How to Get Away with Murder, the protagonists engage in frank discussions without needing to give a passing thought to the many layers of privilege that have lined their paths.

Such narratives proffer a carefully managed HIV status as the only desirable one, short of testing negative. Achieving an undetectable viral load-through realizing, 
accepting, and acting on imperatives of personal responsibility-supposes particular modes of self-knowledge and discipline, but sidesteps questions of access and wealth disparity. Shortly before releasing the "Start Talking" PSA, the CDC endorsed the preexposure prophylactic (PrEP) drug Truvada, which studies have shown to reduce the risk of HIV transmission by up to $92 \%$ (Duffy). However, at a time when medical expenses remain the leading reason for filing for personal bankruptcy in the U.S., access to life-saving or life-enhancing medications remains fraught (Puar, "Coda" 149). Restricted access to health care does not only make HIV survival conditional on material privilege, it actually undermines the very notion of "LGBT equality."

\section{Desiring the State: The Ambivalent Gift of Recognition}

As historian George Chauncey has written, the sense that gay men and lesbians "stood outside the moral boundaries of the nation profoundly shaped the earliest responses to AIDS in the United States" (40). Eventually, that same sense would fuel a larger momentum for legal recognition of queer relationships, including statesponsored modes of enduring, monogamous, productive, and possibly reproductive couplehood. This quest for certified membership in the "intimate public sphere" of U.S. citizenship (Berlant, Queen of America 5) enabled newly rights-bearing queer citizens to retreat to a domestic, private sphere, and to cease conceptualizing HIV/AIDS as central to a marginality to which they might no longer relate.

However, as Judith Butler explains, legitimation is an "ambivalent gift": On the one hand, the state becomes a fantastical site at which "[queer] desire and sexuality are ratified, justified, known, publicly instated, imagined as permanent, durable" and given recognition (Undoing Gender 166, 175). But on the other hand, something pernicious happens to queer sexuality "when it runs through this particular circuit of fantasy" (175). Through the performative "disavowal" of promiscuity, by making queers appear normal, healthy, and capable of accepting monogamous responsibility, gay marriage engenders forms of hierarchy and legitimacy that work to deny recognition and dignity to those who live, and choose to live, sexually and affectively outside of the kinship norms of marriage (Undoing Gender 175; cf. also Warner). By the same token, neoliberal models of state power, which work towards the privatization of public goods, such as health care, encourage forms of sexual citizenship compatible with privatizationwhich have recently grown to include same-sex couples. By granting gay and lesbian couples the right to marry and raise children, the U.S. state incentivizes particular modes of intimacy that favor (re)productive family units. These incentives work on twin levels: through desire (romanticizing the stability of monogamous love) but also coercion (tying health care, inheritance rights, and joint property ownership to marriage).

The monumental transition from death to chronicity, as Jasbir Puar has argued, reframed queerness from a way of dying (from AIDS) to a way of living (with or without AIDS) that could be responsive to, and even desire, state regulation and control (Terrorist Assemblages xii). The move from total exclusion to provisional inclusion-the result of decades-long, sustained activism-has constructed a normative queer subject deserving of legal protection: mostly white, able-bodied, affluent, mainly $\mathrm{G}$, sometimes $\mathrm{L}$, rarely $\mathrm{B}$, and almost never $\mathrm{T}$. However, the desire for state recognition entails a paradox: the paradox of looking to state power to legitimate and certify an identity 
that is, at least in part, constituted by a prior rejection or exclusion from the state. Wendy Brown questions whether the state can even be an appropriate venue to seek resolution for antidemocratic injuries (28). Why, she asks, should one seek redress for an injury from the same entity that inflicted the injury in the first place? Why would we seek protection from the state for our vulnerabilities when those only exist because the state made us vulnerable in the first place? Or is it that the very terms of liberalism -that locate identity as a possession of the individual-actually "[require] the very structure of oppression that freedom emerges to oppose" (Brown 7)? If the goal of gay and lesbian liberation is to compel the state to restore a justice that it is responsible for withholding, then that very premise might limit the kinds of political demands one can articulate-"freedom" and state approval become synonyms. Similarly, petitioning the state for legal recognition as a group requires subsuming internal differences-reducing the complexities of individual identity to the smallest common denominator: prioritizing the needs of some over those of others.

\section{Homonormativity: Whiteness, Health, and Privilege}

The CDC campaign's "Start Talking" tagline is eerily similar to the "SILENCE = DEATH" slogan angrily shouted and painted on posters by ACT UP activists in the late 80 s and early 90s. Both posit speech and discourse as tools of defense against HIV/AIDS. However, their political contexts could not be more different. Originating from within a veritable state of crisis, "SILENCE = DEATH" angrily put neoconservative political institutions on trial that refused to acknowledge and address the human costs of the AIDS crisis. By contrast, "Start Talking" draws its discursive logic from a historical moment in which queer relationships have found a figurative and legal home in the arms of the U.S. nation state. Now that the state is "on our side" and has conditionally legitimated queers as members of the American body politic, the distinction between "straightness" and "queerness" no longer coheres with the fault lines of inclusion and exclusion. Rather, constructions of normative subjectivity have experienced a qualitative shift: heteronormativity (the notion that only cis-gendered, heterosexual, gender-conforming folks constitute "normal" subjectivities) has been partially extended to include homonormativity.

Ino feeding off existing inequities, rather than addressing them, homonormativity is recruitable for economics of "upward redistribution" that privilege the already privileged-and the marginality of the already marginal becomes accelerated (Duggan, Twilight of Equality 128). Homonormativity operates on a curious logic of displacement, one that forecloses on systemic critique and works to fold the "immunocompetent" queer citizen into the American body politic as opposed to excluding them, as in years past. Failing to recognize the economic and the social as intimately connected, a homonormative political movement pursues "identity politics" while sidestepping the material and racial layers of privilege that have animated those identities. ${ }^{6}$ As Agathangelou et al. argue, it is through "displacement and explicit effacement of racial, sexual, and class antagonisms and inequities" that the "good queer citizen" has gained entrance into the fold of the nation, to the detriment and continued exclusion of others (124). To give an example, rather than seeking to make healthcare universal, a homonormative demand would prioritize "domestic partner" benefits for same-sex partners, isolating injustice to the context of monogamous 
couplehood, one that only so happens to involve two people of the same gender (cf. Bernstein Sycamore iii). The circle of inclusion becomes wider, but the circle itself remains exclusive and its racial and class boundaries firmly in place.

The movement for same-sex marriage, to cite an obvious example, has done little to undermine racialized hierarchies of wealth disparity, health, and survival. For Puar, such claims to civic inclusion are not simply demands for equality, but rather demands for "reinstatement of white privilege and rights-rights of property and inheritance in particular" (Terrorist Assemblages 29). The rights and benefits afforded to married spouses, such as tax benefits, inheritance rights, and spousal health insurance, always already presume a materially privileged citizen subject able to partake of those rights. However, if economic and physical survival supersede desires to benefit from a spouse's already precarious health insurance or to bequeath non-existent estates to surviving spouses, then access to marriage in its legal sense loses much of its desirability. By extension, languages that synonymize access to marriage with "equality" begin to sound hollow. Clearly, there are limits to a "gay and lesbian political agenda based on a civil rights strategy, where assimilation into, and replication of, dominant institutions are the goals"-and those limits affect queers of color most direly (Cohen 437).

Ondy if queers, and queers of color in particular, are able to amass sufficient material and social privilege do they become eligible for the institutional protections of citizenship, many of them accorded and administered through marriage. Whiteness, in the words of George Lipsitz, is a "poisonous system of privilege" that works to reproduce itself, in part through endowing marriage with access to wealth-growing benefits (xix). The economic "cash value" that so easily attaches to whiteness, Puar argues, was heavily circumscribed for most queers-until recently (31). To relate this back to our example, the CDC "Start Talking" campaign exemplifies what she might call an "ascendancy of [queer] whiteness" (Terrorist Assemblages 31). By presenting a discursive climate of diversity (in which we see some gay men of color represented), the campaign visually performs inclusiveness but leaves uncritiqued the broader structures of the U.S. health care landscape that preclude many queers from the medical possibilities to which it gestures.

Intruth, HIV-positive African American men are significantly less likely to access HIV care-the result of a toxic mix of poverty, stigma, and mistrust of medical authority (Maulsby et al. 10-25). ${ }^{7}$ Insidiously, the CDC PSA does not so much represent "a conservative, racist formation bent on extermination, but rather [a] liberal one proffering an innocuous inclusion into life" (Puar, Terrorist Assemblages 31). However, this innocuous inclusion masks serious racial disparities. As a recent CDC statistic indicates, African American men who have sex with men are eight times more likely than whites to be diagnosed with HIV (CDC, "HIV Infection Among African Americans). In addition, the CDC states, "African Americans have worse outcomes on the HIV continuum of care, including lower rates of linkage to care, retention in care, being prescribed HIV treatment, and viral suppression" (Puar, Terrorist Assemblages 31). In light of these numbers, one has to wonder: In what ways is "post-AIDS" queer health a marker of racial privilege?

A 2textbook neoliberal narrative, the CDC campaign posits self-policing and consumption as sure roads to good health and happiness by alerting more potential consumers to products' availability. As Jason Read has suggested, neoliberalism posits 
individualized and privatized solutions to social problems; solutions that can literally be bought and sold: "gated communities for concerns about security and safety, bottled water for concerns about water purity, and private schools for failing public schools" (25). In the case of HIV care, neoliberal narratives about being and staying healthy present consumable solutions to a public health problem: condoms, pre-exposure prophylactic medication, or antiretroviral medication that are attainable for some, but not for all. If sickness under conditions of capitalism, as Lauren Berlant has suggested, means nothing more than the inability to work, then we might understand the CDC narratives as a health manual in which health and able-bodiedness resonate in economic terms (Cruel Optimism 95).

A poster child for effective medicalization, the immunocompetent gay man is a Foucauldian homo economicus who works towards healthiness in order to attain economic value. The homo economicus is "an entrepreneur, an entrepreneur of himself" who makes investments in himself so as to maintain his productive potential (Birth of Biopolitics 226). A wholly economic being, his cultural, political, emotional and personal components are broken down, subdivided, and made responsive to the gains of enterprise. A homo economicus is "eminently governable" and "responds [rationally] to systematic modifications artificially introduced into the environment" (Foucault, Birth of Biopolitics 270). If HIV is such a "systematic modification," then the kind of healthiness envisioned and promised by the CDC campaign is informed by precisely such modes of rationality and responsiveness. Docile bodies finely attuned to the demands of neoliberal citizenship are able to withstand moments of personal crisissuch as testing positive for HIV-and transcend them by making consumptive investments in the form of medical treatment. Meanwhile, the continued utility of HIVpositive queer citizens undergirds their fitness for U.S. citizenship in the context of a competitive, free market economy. Trauma and misery are staved off, managed, and transcended-"unruly" and unhealthy bodies attain productive capacities. In this process, deployments of stigma and shame do important work in securing the boundaries of "proper" queer bodies and identities.

\section{AIDS Stigma and Gay Shame: Leaving the "Community of Pariahs"}

Recently, we have witnessed two spectacular instances of AIDS stigma play out in the media: Actor Charlie Sheen's public admission of his HIV status inflamed discussions about a resurgence of AIDS-a discussion largely based on the (longdebunked) notion of heterosexual immunity to HIV (LaMotte). Mere days later, hedge fund manager Martin Shkreli purchased the rights to HIV drug Daraprim and hiked a single tablet's price to several hundred dollars, up from $\$ 13.50$, sparking outrage-an outrage based on the price of the drug, however, not on the commodification of the drug as such (Pollack). These brief re-appearances of AIDS in public discourse notwithstanding, we would do well to remember that the historical roots of AIDS shame in the U.S. context grow much deeper. Deployments of AIDS stigma, as this section will demonstrate, have attached to diverse historical moments-always with the goal of policing, disciplining, and sanitizing sexuality. As an imaginative spectacle, AIDS has also been, and continues to be, anchored to planes of visuality, represented on and through healthy/muscular or dying/gaunt queer bodies. 
Noreffective HIV/AIDS treatments existed in 1989 when Susan Sontag pondered the "metaphorizing" potentialities of AIDS (106). Patients wasted away with high fevers, rapid weight loss, fungal infections, facial deformities, swollen lymph glands, and rare types of cancer. Their ailments visualized a specific kind of suffering and dying-ones that came with a crushing serving of social ostracism. Unlike heart attacks or strokes, AIDS visualized the death of a "community of pariahs": gay men, sex workers, and intravenous drug users (Sontag 126). In Cindy Patton's words, early AIDS narratives amounted to a "discursive death squad" because the deadly potential of AIDS was intimately associated with a certain category of people whose biological death only confirmed that they had been undeserving of life all along (132).

Two years before Sontag, in "Is the Rectum a Grave?," Leo Bersani had explained how the (homo)sexual self came to represent a simultaneously suicidal and murderous figure, asking how gayness and homosexual became implicated in a cultural logic of "those being killed are [also] killers" (211). In the heterosexual imaginary, AIDS produced tremendous uncertainty about bodily and sexual integrity, as well as about the moral health of the "family" (203). By definition, cultural narratives about "family" excluded the disease-ridden and immoral "homosexuals" from sexual legitimacy. AIDS exacerbated the stigma of homosexuality and precipitated a "crisis over the entire framing of knowledge," as Simon Watney has suggested (quoted in Bersani 198). AIDS also called into question core tenets of sexual self-determination-sexual liberation, i.e. the freedom to freely choose one or many sexual partner(s), now harbored infectious and lethal dangers. The AIDS epidemic, and the vitriolic public responses to it, made clear how ephemeral feelings of sexual liberation among the male gay community had been. As one person living with AIDS remorsefully commented, "the belief that was handed to me was that sex was liberating and more sex was more liberating" (D'Emilio and Freedman 355).

Indthe earlier AIDS years, promiscuity signified quasi-suicidal intentions, and receptive anal sex in particular hinted at a latent desire to self-destruct. Passivity was taken to show lack of authority, self-determination, and assertiveness-sexuality reduced to suicidal, receptive pleasure-and also represented a certain indifference to murder: a wholesale rejection of the "moral" tenets of social life. The receptive anal sex "homosexuals" were presumably having cast a wide metaphorical shadow, with sometimes deadly consequences. Bersani discusses a 1987 incident in Arcadia, Florida, when unknown arsonists burned a home to the ground. A family with three hemophiliac children, who required frequent blood transfusions and were presumed to have contracted HIV, lived in the home and the children's seropositive status enraged the arsonists to a point where they felt the children needed to be killed. AIDS heightened heterosexual anxiety about the dangers of homosexuality-and what it might mean epistemologically for a man to derive pleasure from receptive anal sexand became a "metonym for cultural anxieties about the body," as Carrie Sandahl has written (50). Since its early days, AIDS had been so inextricable from notions of sexual deviance that even "innocent" children became metaphorical symbols of deviant sexuality. Threats of contamination made anyone with a blood-related condition, even hemophiliac children, into potential diseased "queers" whose deaths became a justifiable moral imperative to preserve the "family" (Bersani 204). One had to wonder, Bersani writes, how the sight of three hemophiliac children could come to represent "the infinitely ... seductive and intolerable man, legs high in the air, unable to refuse 
the suicidal ecstasy of being a woman," conjuring a specter of sexual contagion in even the most non-sexual of contexts (212).

Michel Foucault once described sexuality as an "especially dense transfer point for relations of power," arguing that relating to others sexually, or even thinking about others in sexual terms, always entails a negotiation of power relations (History of Sexuality 103). Those power relations become differentially coded-vaginal intercourse as normal, other sexual practices as deviant-and anal sex comes to signify as a very particular power relation. In and of itself, anal sex is not uniquely revelatory of power, as Bersani hastens to add, but rather makes visible the "shifting experience[s] that every human being has of his or her body's capacity, to control and to manipulate the world beyond the self" (216). In other words, anal sex brings to the fore a relationship between sex and power that unmasks sex as a precarious oscillation between mastery and subordination. Normative gender presumptions figure centrally in discourses of normative sexuality, and anal sex calls these presumptions into question. As Patton suggests, "desires centering on the anus cannot infallibly be stabilized to produce 'heterosexuality' and anal sex becomes a key site of (hetero)sexual danger of sexual reference" (118). To paraphrase Patton in Butlerian terminology, anal sex diffuses the "heterosexual matrix" meant to ensure and enforce the internal coherence of gender and sexuality, and since the rectum cannot reliably signify male vis-à-vis female anatomy, it poses the risk and dangers of diffusion (cf. Butler, Gender Trouble 6).

More than two decades later, those same modalities of risk and diffusion become subject to vigorous linguistic management. The attributes "undetectable," "virally suppressed," or "having a high CD4 count" serve to rehabilitate spoiled gay identity, as a shield against the stigmatizing historical meanings of AIDS. As PrEP and antiretroviral drugs save lives, they also make unhealthy queer bodies healthy and fit to enjoy the political rights so hard won-rights that gesture towards sexual normalcy and a repudiation of AIDS. As "undetectable" has become an attribute used to describe oneself on gay dating apps such as Grindr, the implication is that the "undetectable" body has transcended the stigma of being "too queer"-and the "detectable" ones remain too queer to move beyond AIDS (cf. Warner 50).

Insterms of visuality, the admiration for masculinity and muscularity in many gay communities is well documented and need not be rehearsed here. However, it might be illuminating to think about muscular gay bodies-represented on gay dating apps, in public health campaigns or in the media-as visual ambassadors of a post-AIDS gay era in which healthiness does not only signify sexual attractiveness, but also potential evidence of successful HIV management. By the same logic, the shame of being an AIDS-stricken queer, of visibly embodying the failure to care for one's own body is unrepresentable, precisely because AIDS amounts to metaphorical and immunological punishment for queer sexual deviance. The image of the "healthy" undetectable subject diverges starkly from the historical visuality of the AIDS "victim" as a physically and visually degenerating body-thin, gaunt, covered with lesions. In that way, "undetectability" becomes a way to mark one's distance from historical imagery of the diseased, uncontrolled, and deadly queerness of AIDS. Abdicating and negating communal responsibility through this linguistic strategy are ways of abdicating and negating membership in a stigmatized "community of pariahs," to borrow Sontag's phrase (113). 
So 3 how can we account for the forces invested in instantiating "post-AIDS" fantasies and marking HIV/AIDS as a "purely medical, abject existence" that is radically outside the reality of "normal" gay citizens? In the words of Butler, "to 'refer' naively or directly to... an extra-discursive object will always require the prior delimitation of the extra-discursive" (Bodies That Matter xx). Only once a particular cultural authority has marked something as beyond and outside of culture can it signify as (but never actually be) extra-cultural or extra-discursive. In other words, "post-AIDS" fantasies rely for sustenance on a constitutive outside: on cautionary, HIV-positive examples. Representations of such "anti"-HIV figures tap into the same arsenals of stigma and shame from which the newly enfranchised LGBT American citizen has supposedly gained immunity. At the very same time, the abject "bugchaser" figure-an HIVnegative man who has unprotected sex with HIV-positive men in search of being infected-reveals the discursive limits of AIDS disavowal. To borrow Foucauldian terminology, the "present castigation of [visibly] positive gay men can best be understood... as modes of governmentality" that deploy virulent stigma in order to frame seropositivity as antithetical to LGBT citizenship (Race 86).

ImLouise Hogarth's 2003 documentary film The Gift, a number of bugchasers recount, with an emotional rawness often bordering on the unbearable, their journeys to infection. Their narrations are juxtaposed with shots of an HIV support group, whose members suffer from various physical disabilities related to their seropositivity and can only shake their heads at the bugchasers (Hogarth). While the film succeeds in sketching out the potential consequences of HIV infection, it fails to understand its bugchasing protagonists as by-creations of a homonormative value system in which sexual practices other than monogamous, hygienic, and safer sex are shunned, feared, and stigmatized-a value system which, ironically, developed in response to the stigma encountered by previous AIDS generations.

Knowing what we know now, no one in their right mind could possibly want HIV, or so the narrative suggests. And armed with that simple truth, the formerly stigmatized become stigmatizers. Rather than attending to this irony, the film is content to mark the young men as tragic, fallen figures whose courtship of death makes them, if not mentally ill, clearly deluded. Neglecting to explore the psychological motives that may move these men to desire a fatal syndrome (beyond alluding to survivor's guilt or not "having to worry about it anymore"), the film misses an opportunity to explore the phenomenon in more depth. In a particularly dramatic moment, Doug Hitzel, one of the film's protagonists, intones to the camera as if speaking to his pre-HIV self, "Are you happy now? Happy now?" (Hogarth; Gonzalez 92-96) If undetectability is the HIV-positive dream scenario, bugchasing is the nightmare: Two discursive positionalities that purport to describe diametric opposites but are, in fact, two sides of the same coin: Both bugchasers and "undetectables" try to exorcise the ghosts of AIDS-one through erotic courting and the other through radical ejection. But try as they might, both remain haunted.

Atthough bugchasers might, statistically, be a rare phenomenon, the centrality of AIDS repudiation within homonormative subjectivity has revived historical specters of AIDS stigma. In fact, Octavio Gonzalez argues that dramatized representations of HIV/AIDS "victims" have made possible a re-medicalization of the ostensibly normalized queer body, focusing in on moments when the treatments available and LGBT civil "rights" afforded fail to yield the desired "post-AIDS" results. In other words, 
unsafe and risky sexual behaviors have come to determine "inclusive citizenship practices within gay and lesbian politics" (McNamara 239). The HIV-positive or HIVdesiring queer body-in its overwhelming queerness-is so disturbing because it refuses to be erased and disciplined: "it persists as the queer love that dared speak its name" (Gonzalez 101). To be clear: the point here is not to belittle the physical and emotional realities of HIV/AIDS. Rather, it is to critique the punitive cultural impulses that have replaced one form of AIDS stigma with a new iteration, policing, disciplining, and enforcing sexual normativity-not from the "outside" but from the "inside."

\section{HIV and Disability: Fantasies of Inclusivity}

Formally, the Americans with Disabilities Act (ADA) recognizes people with HIV and AIDS, symptomatic or asymptomatic, as disabled because they are understood to have "physical impairments that substantially limit one or more major life activities" (Sandahl 49). In reality, however, poor people, people of color, and prisoners are disproportionately prosecuted and incarcerated for failing to disclose an HIVpositive status, knowingly or not, to sexual partners (Román 8). "Undetectability" discourses instantiate racialized and classed norms of disability: some get to be undetectable as others get detected. ${ }^{8}$ Ironically, legal protection for some folks with HIV coincides with protection from other people with HIV (Román 8). The duplicitous nature of such discourses-liberating and enfranchising some while incarcerating and disenfranchising others-illustrates what David Mitchell and Sharon Snyder have described as the "bodily-based nature of privilege in late capitalist societies" (13). As post-AIDS queer healthiness works to uphold the appearance of "equality," its differential structural accessibility reduces the legislative status of HIV/AIDS as a "protected" disability to absurdity. As Dean Spade has observed, "declarations of universal rights often actually mask and perpetuate the structured conditions of harm and disparity" that affect the very groups afforded legal rights (Spade 30). In that sense, HIV/AIDS in the context of a disability rights framework reveals a dissonance between the legal rights attained (such as inclusion into the ADA) and the realities of lived experience. ${ }^{9}$

Bysand large, the same LGBT citizens privileged enough to enjoy the material benefits that same-sex marriage and legal inclusion conditionally afford tend to lead "post-AIDS" lives. An impoverished notion of "equality"-defined in terms of access to a small number of conservatizing institutions-works to maintain ableist, and for many unattainable, standards of the "good life." As Robert McRuer reminds us, "compulsory able-bodiedness" is invariably interwoven with logics of normative sexuality-logics that are mobile and have grown to include forms of LGBT sexuality ("Compulsory AbleBodiedness" 301). What may be called "post-marriage equality homophobia" manifests in flexible registers in which ableist fantasies of inclusivity mask the structural exclusions they themselves vigorously maintain, with toxic consequences for HIV/AIDS prevention and care. This "new" homophobia is deeply disabling because it commodifies health as a material privilege and folds HIV/AIDS care directly into this hierarchy. But at the very same time, it is en-abling for others.

Disabilities other than HIV/AIDS, in fact, may serve as visual representation of heroism and evidence of sacrificial citizenship. In a post-“Don't Ask Don't Tell” world, the right to serve openly in the U.S. military has gained LGB (no T yet) service men and 
women the right to be injured, disabled or disfigured. Further still, injured or disabled gay men and lesbians may have their injuries understood as sustained by fully "out," authentic, and heroic national citizens. The example of military service, thus, indicates that disability is not always antithetical to gay and lesbian rights, but can also exhibit and certify the very presence of "rights." It is this discursive flexibility-in which military disabilities may resonate as heroic and deserving of public recognition while HIV infection remains a personal "problem"-that indicates the unequal value placed on the health and able-bodiedness of queer U.S. citizen subjects. Sexuality, and control and containment thereof, functions as the fault line.

Inour times of LGBT liberalism, the ways in which we talk, or fail to talk, about HIV tend to default to tropes of normative sexuality and citizenship in which ablebodiedness, secured by disciplined, responsible sexuality, remains an unspoken assumption. As Tim Dean has written, "[normal] sex... requires a normal body"-and a normal body also requires normal(ized) sex in order to signify as normal (144). However, we might be witnessing a reinterpretation of what may count as "normal sex" and the bodies eligible for such normalcy (143-5). In Gonzalez's words, "dominant identitarian fictions... remain territorialized as regimes of able bodies and hygienic sexual desire" that work to streamline the bodies eligible for and the desires permissible under the umbrella of "identity" (106). Where AIDS used to be a definite marker of pathology and exclusion, now HIV (if managed and suppressed) is no longer by default a barrier to civic participation.

Disability theory enacts a critical sensibility well suited to attending to the violent erasures effected by neoliberal LGBT rights-based movements. Scholars of dis/ ability critique the unequal valuation of bodies on the basis of arbitrary distinctions between "able" and "disabled" bodies. Building on Tobin Siebers's work on the medical and social models of disability, I argue that HIV-as a chronic illness residing at intersections of medical management and stigma-complicates and particularizes this distinction. While the "medical model" locates disability as an individual illness that requires medical intervention, the "social model" opposes this very medicalization and draws attention to the social and built environments that produce "disability in bodies and require interventions at the level of social justice" (Siebers 25).

Although HIV/AIDS has historically engendered fierce social stigma, and would thus appear to fit the "social model" of disability, it also troubles dichotomous disability models. Ultimately, living and surviving with the HI virus remains a matter of medical treatment. There are very "real," bodily consequences to suffering from HIV/ AIDS that cannot be explained away by reference to a "socially constructed" reality in which certain bodies are disabled and stigmatized when nothing is actually amiss. To the contrary, AIDS is a serious medical crisis and the syndrome will most likely kill those infected unless they receive proper treatment. It is at this uneasy juncturemedical management of a virus on the one hand and confronting social stigmatization on the other-that attention to HIV/AIDS discourses complicates existing disability models in their emphasis on the socially constructed nature of dis/ability. HIV/AIDS is neither a purely medical nor a purely social disability because its effects manifest themselves differently for different people. Those whose health insurance covers antiretroviral regimens, and those with supportive families and employers, are able to navigate their HIV status and live their lives with a chronic but manageable illness. Others may not be so lucky. 
Assqueer health becomes instrumentalized by a homonormative disciplinary regime that equates health with moral "normalcy," such health(iness) comes to determine belonging to the U.S. American "imagined community" (Anderson). Louis Althusser's notion of "interpellation" might prove useful to critique the ways in which the "new gay equality" hails rights-bearing queers into health, only to then charge a premium for access to this health. Althusser reminds us that it is institutions, and the ideological state apparatus supporting them, that construct subjectivities: we know who we are through the identities accorded to us by the institutions into which we are discursively hailed, as well as through the roles we occupy within them (Althusser). If the nation state is a paramount institution in anyone's life-in which membership is compulsory but organized hierarchically-then we might understand how the role of (queer) citizen is secured through modalities of queer health(iness). After being "hailed" into the American nation state as deserving citizens, queers are expected to prove and maintain their worthiness by remaining healthy and productive. In that sense, queer health is as much a desired state as it is a "prescribed state and an ideological position" (Metzl 2).

Ideologies of health and able-bodiedness have been critical to the transition from "queer outsiders" to queer citizens. As a result, fantasies of a happy, "post-AIDS" American age are implicit to many LGBT rights claims: only non-disabled folks, with well managed HIV infection should they happen to be positive, are meant to enjoy marital bliss, serve in the military, and raise children, all in anticipation of a (re)productive future to be lived. Pushing back against this logic, a disability studies approach to HIV makes visible the degree to which queer health is made to signify fitness for citizenship at the same time as it is commodified and made differentially accessible.

Queer studies and disability studies have convergent interests: Queer studies critiques and illuminates the cultural logics that have given rise to the insidious notion that AIDS in America has ceased to matter. Disability studies is concerned with how social ideologies perpetuate social and material conditions that enshrine inequalities between different "kinds" of bodies and subjectvities. In tandem, queer studies and disability studies may deconstruct the discursive systems that restrict access to HIV care while at the same time making HIV management a precondition for the enjoyment of "LGBT rights." In fact, queer and disability studies follow organically from one another: when critiquing the persistence of AIDS stigma, a simultaneous critique of the ideologies of able-bodiedness that undergird homonormative norms of identity is inevitable. These important critiques have already begun, most notably in the work of McRuer, and remain ever urgent. McRuer calls for a "critical investment" in disability that directs "our attention back to... productively unruly bodies" ("Critical Investments" 236). Such an investment does not so much call for inclusion into existing administrative structures, but demands access to "public spaces and conversations currently configured to reproduce only the limited perspective of the able body" (236).

\section{Conclusion: The Price of Undetectability}

Intour current times of LGBT liberalism, it is time to name the cultural mechanisms that have made an "undetectable," post-AIDS world seem well within reach of some while putting that same world well out of reach for others. Following the 
historical displacement of activism (removing accountability from the "system" and strapping it to the back of the individual), AIDS care work today is often carried out by chronically underfunded non-profit organizations. More broadly, it seems questionable whether today's dominant narratives of LGBT inclusion (such as anti-bullying education, "It Gets Better"-like encouragement campaigns or private fundraisers) are adequate for addressing deeply structural problems: queer youth homelessness, suicide prevention, and racial disparities in health care access.

Inthe U.S. American context, HIV-positive folk who lack access to financial means and quality health care have been made to pay a steep price for mainstream desires for marriage, military service, and domestic bliss. The emphasis on privacy within LGBT identity politics has drained resources, attention, and energy from structural AIDS work. Although AIDS used to be the central "raison d'être" for gay and lesbian politics-and in fact catalyzed the initial queer "turn" towards state recognition -that centrality has been replaced by lack of interest at best and stigmatization at worst. ACT UP and other activist groups understood a fundamental truth: AIDS never was, still is not, and never will be a private problem-it is a collective, structural, public health issue. HIV narratives as seen in How To Get Away with Murder or the CDC's "Start Talking" campaign model responsible, happy post-AIDS gay lives, but make invisible the layers of racial, political, and economic privilege that animate and sustain them.

Tasbe sure, the CDC is doing important work to address the vulnerabilities of queer men of color for HIV infection and their lack of access to quality care. Its efforts include an initiative called "Take Charge. Get Tested." to encourage African Americans to get tested for HIV. It also provides resources and funding to health departments that further the goals of its "High Impact Prevention" strategy by facilitating access of communities of color to HIV treatment. And even the "Start Talking" campaign is a gigantic leap forward from the silences that stymied HIV prevention efforts in the 80s and 90s (cf. Warner). And, ultimately, the campaign may well be effective for the populations which it targets. However, the logics informing these narratives remain wedded to modes of restriction-premised not on total neglect, but on conditional inclusion.

Atthis moment, LGBT rights in the U.S. are under attack from multiple frontsbe it in the form of "religious freedom" legislation in Georgia or Arizona, so-called "bathroom ordinances" in Arkansas, or "non-discrimination" policies in North Carolina that criminalize same-gender and transgender people in various ways (cf. ACLU, "AntiLGBT Religious Exemption Legislation"). These assaults on the civil rights of LGBT Americans should move us to recalibrate our porous notions of "equality" and "progress." At the same time, the current challenges might also attune us to the many structural elisions that pursuits of LGBT "privacy" have engendered: hierarchies of race, class, gender, and HIV/AIDS work chief among them. If LGBT politics hopes to move beyond a singular focus on the individual, it must continuously challenge linear narratives that suggest that once certain legal rights and protections have been attained, discrimination and injustice are remnants of a distant past. In fact, LGBT "progress" might be understood less in terms of what it has achieved but in terms of its many shortcomings-understood as a dialectic that recognizes exclusion as an unacknowledged function of "progress," rather than as its antithesis. ${ }^{10}$

Swoh an exploration must entail rigorous critiques of "post-AIDS" fantasies, as those suggest a unidirectional historical trajectory and embed queer history in 
narratives of progress and linearity-narratives that map onto few realities (Román 1-2). Troublingly, "end-of-AIDS" rhetoric has coincided with a perceived shift in the demographics most at risk: away from the white queer U.S. citizens to disenfranchised, faceless communities of color-in the U.S. and in African countries alike. ACT UP activists understood that loudness and visibility mattered; by contrast, "undetectability" draws on registers of silence and invisibility. Rather than acquiescing in impulses for silence, it is time to move loud, confident, critical, more inclusive conversations about AIDS squarely back into the realm of LGBT politics and to claim systemic critique as a cornerstone of those politics. Too much remains at stake. "Undetectable" cannot be the end of public discourse about AIDS-it can only be the beginning of more inclusive tomorrows. It has gotten better, yes-but for whom? And at whose expense?

\section{BIBLIOGRAPHY}

Agathangelou, Anna M., M. Daniel Bassichis, and Tamara L. Spira. "Intimate Investments: Homonormativity, Global Lockdown, and the Seductions of Empire." Radical History Review 100 (2008): 120-143. Print.

Althusser, Louis. "Ideology and Ideological State Apparatuses." Lenin and Philosophy, and Other Essays. Louis Althusser, trans. Ben Brewster. New York: Monthly Review Press, 2001. 85-126. Print. American Civil Liberties Union (ACLU). “Anti-LGBT Religious Exemption Legislation Across the Country." 9 May 2016.

https://www.aclu.org/anti-lgbt-religious-exemption-legislation-across-country

Anderson, Benedict. Imagined Communities: Reflections on the Origin and Spread of Nationalism. New York: Verso, 2006. Print.

Berlant, Lauren. Cruel Optimism. Durham and London: Duke University Press, 2011. Print.

----. The Queen of America Goes to Washington City: Essays on Sex and Citizenship. Durham, NC: Duke University Press, 1997. Print.

Bernstein Sycamore, Mattilda, ed. That's Revolting! Queer Strategies for Resisting Assimilation. Brooklyn, NY: Soft Skull Press, 2008. Print.

Bersani, Leo. "Is the Rectum a Grave?" October 43 (187): 197-222. Print.

Brown, Wendy. States of Injury: Power and Freedom in Late Modernity. Princeton, NJ: Princeton University Press, 1995. Print.

Butler, Judith. Gender Trouble: Feminism and the Subversion of Identity. New York and London: Routledge, 1990. Print.

----. Undoing Gender. New York and London: Routledge, 2004. Print.

Centers for Disease Control and Prevention (CDC). "HIV Infection Among African Americans." 29 Sep 2015. Web. 
http://www.cdc.gov/hiv/group/racialethnic/africanamericans/

Centers for Disease Control and Prevention (CDC). "Start Talking. Stop HIV." 15 Sep 2015. Web http://www.cdc.gov/actagainstaids/campaigns/starttalking/index.html

Chauncey, George. Why Marriage? The History Shaping Today's Debate. New York: Basic Books, 2004. Print.

Cohen, Cathy. "Punks, Bulldaggers, and Welfare Queens: The Radical Potential of Queer Politics?" GLQ 3 (1997): 437-65. Print.

Crimp, Douglas with Adam Rolston. AIDS Demo Graphics. Seattle: Bay Press, 1990. Print.

D’Emilio, John, and Estelle B. Freedman. Intimate Matters: A History of Sexuality in America. Chicago and London: The University of Chicago Press, 2012 (third edition).

Dean, Tim. "Queer." Keywords for Disability Studies. Ed. Rachel Adams, Benjamin Reiss, and David Serlin. New York: New York University Press, 2015. 143-5.

Duffy, Nick. "US: CDC launches ad campaign recommending HIV-preventative drugs." Pink News. 9 Sep 2009. Web.

http://www.pinknews.co.uk/2014/05/25/us-cdc-launches-ad-campaign-recommending-hivpreventative-drugs/

Duggan, Lisa. "The New Homonormativity: The Sexual Politics of Neoliberalism." Materializing Democracy: Toward a Revitalized Cultural Politics. Ed.Russ Castronovo and Dana D. Nelson. Durham, NC: Duke University Press, 2002. 175-194. Print.

----. The Twilight of Equality? Neoliberalism, Cultural Politics, and the Attack on Democracy. Boston: Beacon Press, 2003. Print.

Edelman, Lee. "The Plague of Discourse: Politics, Literary Theory, and AIDS. The Postmodern Turn: New Perspectives on Social Theory. Ed. Steven Seidman. Cambridge and New York, Cambridge University Press. 299-312. Print.

Foucault, Michel. The Birth of Biopolitics: Lectures at the Collège de France 1978-1979. Ed. Michel Senellart. Trans. Graham Burchell.New York: Picador, 2008. Print.

----. The History of Sexuality. Volume 1: An Introduction. Trans. Robert Hurley. New York: Random House, 1990. Print.

“HIV’s Toll on Black and Latino Men.” Editorial. New York Times, 29 Feb 2016. Web.

http://www.nytimes.com/2016/02/29/opinion/hivs-toll-on-black-and-latino-men.html Gonzalez, Ocatavio R. "Tracking the Bugchaser: Giving "The Gift” of HIV/AIDS." Cultural Critique 75 (Spring 2010): 82-113. Print.

LaMotte, Sandee. "Charlie Sheen, stigma and how HIV is the 'new closet."' CNN. Web.

http://www.cnn.com/2015/11/17/health/charlie-sheen-hiv-stigma/

Lipsitz, George. The Possessive Investment in Whiteness: How White People Profit from Identity Politics. Philadelphia: Temple University Press, 2006. Print.

Maulsby, Cathy, Greg Millet, et al. "HIV Among Black Men Who Have Sex with Men (MSM) in the United States: A Review of the Literature" AIDS and Behavior 18 (2014): 10-25. Print. 
McNamara, Michael. "Cumming to Terms: Bareback Pornography, Homonormativity, and Queer Survival in the Time of HIV/AIDS." The Moral Panics of Sexuality. Ed. Breanne Fahs, Mary L. Dudy and Sarah Stage. New York: Palgrave Macmillan, 2013. 226-244. Print.

McRuer, Robert. “Compulsory Able-Bodiedness and Queer/Disabled Existence.” The Disability Studies Reader. Ed. Lennard J. Davis. New York and London: Routledge, 2006. 301-308. Print.

----. “Critical Investments: AIDS, Christopher Reeve, and Queer/Disability Studies." Journal of Medical Humanities 23, 3-4 (2002): 221-236. Print.

Metzl, Jonathan M. “Introduction: Why Against Health?” Against Health: How Health Became the New Morality. Ed. Jonathan M. Metzl and Anna Kirkland. New York and London: New York University Press, 2010. 1-11. Print.

Mitchell, David T. with Sharon L. Snyder. The Biopolitics of Disability: Neoliberalism, Ablenationalism, and Peripheral Embodiment. Ann Arbor: University of Michigan Press, 2015. Print.

Patton, Cindy. Inventing AIDS. New York: Routledge, 1990. Print.

Pollack, Andrew. “Drug Price Goes From \$13.50 to \$750, Overnight." New York Times, 20 Sep 2015. Web.

http://www.nytimes.com/2015/09/21/business/a-huge-overnight-increase-in-a-drugs-priceraises-protests.html

Puar, Jasbir K. “Coda: The Cost of Getting Better: Suicide, Sensation, Switchpoints.” GLQ 18 (2012): 13-28. Print.

----. Terrorist Assemblages: Homonationalism in Queer Times. Durham and London: Duke University Press, 2007. Print.

Race, Kane. “The Undetectable Crisis: Changing Technologies of Risk." Sexualities 4.2 (2001): 167-189. Print.

Read, Jason. "A Genealogy of Homo-Economicus: Neoliberalism and the Production of Subjectivity." Foucault Studies 6 (2009): 25-36. Print.

Román, David. "Not-About-AIDS.” GLQ 6, 1 (2000): 1-28. Print.

Sandahl, Carrie. "Performing Metaphors: AIDS, Disability, and Technology." Contemporary Theatre Review 3 (2001): 49-60. Print.

Sontag, Susan. Illness as Metaphor and AIDS and Its Metaphors. New York: Picador, 2001. Print.

Spade, Dean. The Normal Life: Administrative Violence, Critical Trans Politics, and the Limits of Law. Durham and London: Duke University Press, 2011. Print.

Stein, Marc. Rethinking the Gay and Lesbian Movement. New York and London: Routledge, 2012. Print.

The Gift. Dir. Louise Hogarth. Dream Out Loud Productions, 2003. Documentary Film.

Warner, Michael. The Trouble With Normal: Sex, Politics, and the Ethics of Queer Life. Cambridge, MA: Harvard University Press, 1999. Print.

\section{NOTES}

1. The author wishes to thank the anonymous peer reviewer, Leisa Meyer and Kara Thompson for their careful and thoughtful criticism of the manuscript. Thank you also to the participants of 
the panel "Sites of Trauma and the Making of Disability," chaired by Lynn Adrian, at the 2015 Annual Meeting of the American Studies Association (ASA) in Toronto for their helpful feedback and input. Special thanks to the Office of Graduate Studies and Research and the Reves Center for International Studies at the College of William and Mary for generously supporting my travel to this conference.

2. Columnist Dan Savage coined the term "monogamish" to refer to relationships that, while mostly monogamous, allow for certain amounts of flexibility. Savage argues that "monogamish" relationships have a greater chance at longevity because they recognize the undue and unrealistic pressures of sexual exclusivity.

3. Somerville particularizes histories of "homosexuality" as an identity category beginning in late nineteenth century America, demonstrating that the binary distinctions of "homo-" vs. "heterosexual" emerged alongside and through the "black/white" dichotomy; Siobhan B. Somerville, Queering the Color Line: Race and the Invention of Homosexuality in American Culture. Durham and London: Duke University Press, 2000.

4. Brier complicates the notion that the Reagan administration was oblivious to HIV/AIDS, arguing instead that HIV/AIDS inspired a great deal of internal conflict in the conservative movement; Jennifer Brier, Infectious Ideas: U.S. Political Responses to the AIDS Crisis. Chapel Hill and London: University of North Carolina Press, 2009.

5. This subject matter was given extensive cinematic treatment in the Academy Award-winning film Philadelphia (1995). Tom Hanks's character, an attorney dying from AIDS, sues the law firm from which he was fired, he alleges, for being gay and suffering from AIDS-related illnesses. His employers claims ignorance of his homosexuality and sickness but ultimately lose the trial.

6. See D'Emilio for an account of the formation of gay identity and its relationship to the development of industrialization and capitalism; John D'Emilio, "Capitalism and Gay Identity." Making Trouble: Essays on Gay History, Politics, and the University. Ed. John D'Emilio. New York and London: Routledge, 1992. 3-16.

7. According to Thomas and Crouse Quinn, fears of medical abuse and government-endorsed genocide have been rampant in African American communities since the infamous Tuskegee Syphilis experiment, 1932-1972, complicating HIV/AIDS prevention and education efforts; Stephen B. Thomas and Sandra Crouse Quinn. "The Tuskegee Syphilis Study, 1932-1972: Implications for HIV Education and AIDS Risk Education in the Black Community." Tuskegee's Truths: Rethinking the Tuskegee Syphilis Study. Ed. Susan M. Reverby. Chapel Hill and London: University of North Carolina Press, 2000. 404-17.

8. Here I paraphrase Rinaldo Walcott, who made a remark to this effect in response to David Román's talk at the 2015 Annual Meeting of the American Studies Association in Toronto. Walcott and Román were part of a panel titled, "Re/Centering AIDS in the Age of Gay Liberalism," chaired by Robert F. Reid-Pharr.

9. This insight is central to the work of Kimberlé Crenshaw and other critical race theorists.

10. I borrow the "dialectic" terminology from Adorno and Horkheimer, who theorize historical narratives and trajectories as ideological constructions rather than inevitable "facts"; Max Horkheimer and Theodor Adorno. Dialectic of Enlightenment: Philosophical Fragments. Palo Alto: Stanford University Press, 2007. 


\section{ABSTRACTS}

As medical advances have made HIV survival possible, narratives of "undetectable" viral loads often fail to account for the multiple layers of racial and political privilege that animate and sustain them. For example, African American men who have sex with men are eight times more likely than whites to be diagnosed with HIV, and one in two gay black men will likely be diagnosed with HIV in his lifetime-and African Americans face low rates of access to and retention in HIV care. Drawing on dis/ability and queer theory, this article critiques the ways in which "undetectability" discourses proffer AIDS erasure, whiteness, and ideologies of ablebodiedness as central to homonormative LGBT identity politics. Based in normative modes of disciplinary, hygienic sexuality, narratives and realities of carefully managed HIV infection emerge in support of LGBT desires for state recognition. In this process, an emphasis on personal, rather than systemic, responsibility has tied HIV care and survival to grids of racial, political, and ultimately individual privilege. Weighing the ethical residues of LGBT rights "victories," this essay argues that access to the private spheres of marriage, child-rearing, and inheritance has come at the expense of the health of vulnerable populations and breathed new life into specters of homophobia and AIDS stigma.

\section{INDEX}

Keywords: AIDS stigma, disability studies, HIV/AIDS, homonormativity, identity politics, LGBT rights, neoliberalism, queer health, race

\section{AUTHOR}

JAN HUEBENTHAL

College of William and Mary 